\title{
Lymphatic Vessel Endothelial Hyaluronic Acid Receptor 1
}

National Cancer Institute

\section{Source}

National Cancer Institute. Lymphatic Vessel Endothelial Hyaluronic Acid Receptor 1. NCI

Thesaurus. Code C97289.

Lymphatic vessel endothelial hyaluronic acid receptor 1 (322 aa, 35 kDa) is encoded by the human LYVE1 gene. This protein is involved in both binding and localization of hyaluronan. 